\title{
Occupational Health and Safety Hazards in Rice Farming in Ghana
}

\author{
Lebbaeus Asamani \\ Department of Education and Psychology, College of Education Studies, University of Cape Coast, Cape Coast- \\ Ghana
}

\begin{abstract}
The paper explored specific hazards prevalent in rice farming in Ghana. Ten respondents, including rice irrigation scheme managers, extension officers and rice farmers, were interviewed and observed in a qualitative study. The deductive thematic analysis was use to analyse the transcribed interview data and themes were organised on the semantic level. It emerged that rice farmers in Ghana were exposed to myriad of biological, ergonomic, physical and chemical health and safety hazards. These hazards have enormous health and safety implications for the farmers, if preventive measures are not put in place. The need for appropriate personal protective equipment and protective wears are high recommended given that most of the hazards identified are inherent in the rice farming process.
\end{abstract}

Keywords: Health and safety hazards, Rice farm workers, production agriculture, biological hazards, ergonomic hazards

DOI: $10.7176 / \mathrm{EJBM} / 12-21-10$

Publication date:July $31^{\text {st }} 2020$

\section{Introduction}

Farm workers are exposed to myriad of hazards in their farms. Rice farmers especially encounter numerous hazards due to the nature of environment they work. Kumphon (2009) indicated that rice farmers are exposed to physical, chemical, biological, and ergonomic hazards. Biological hazards are encountered when the work requires that people come into contact with insects, animals, dangerous plants or people. Working in the rice farm may expose the farmers to a variety of biological hazards. Physical hazards on the other hand are things at the workplace that can cause harm to the worker when he or she has not even touched or come into contact with them. Examples are exposure to sun and other extreme weather conditions, continuous loud noise etc. Other situations and conditions that can cause harm, health related problems and even death are also referred to as safety hazards. For instance slippery bonds in the rice fields, sharp work tools or objects are safety hazards. Rice farming involves a lot of these hazards.

Another form of hazard is ergonomic hazard which represents conditions or situations that occur when the type of work and body positions put strain on the body parts of the worker. Ergonomic Hazards in rice farming may include, frequent lifting of bag of rice or fertilizer, awkward sustained work posture, awkward movements, especially if they are repetitive, as in weeding or transplanting of seedlings. These have the potential of causing health challenges to the farmers. Chemical hazards involve exposure to any chemical at the workplace in any form, solid, liquid or gas. Some agrochemicals can cause illness, skin irritation, or breathing problems. Rice farmers use a variety of agrochemicals to control weed and pests; and also fertilizers to fertilize the soil. Some farmers also burn the field during land preparation and the fumes that come from such could pose health problems.

Occupational hazards are features of the workplace that are likely to cause harm or damage to persons or properties (Asumeng, Asamani, Afful, \& Agyemang, 2015). Hazards only present potential to cause harm and whether the harm actually occurs or not depends on circumstances such as the amount of hazards exposure, the extent of the risk factors present and how long one has been exposed to the risk factors (Asumeng et al., 2015). Workers at any work setting are exposed to various health and safety hazards which lead to serious health consequences and in some cases, deaths on daily basis (Concha-Barrientos, Nelson, Driscoll, Steenland, Punnett, Fingerhut, \& Corvalan, 2004).

There is a conceptual difference between hazard and risk. Whereas hazards only present potential to cause harm, risk on the other hand represents the likelihood that exposure to a given hazard would lead to harm or damage to a person, the health of the person or damage to the environment (Ministry of Health, Ghana, 2010). The likelihood of injury or ill health resulting from a hazard is a function of the nature of the hazard and the control measures put in place to control or manage the hazards (Asumeng et al., 2015). Thus, the control measures put in place act as intervening variables in the link between hazards exposure and safety performance. These measures include safety management systems, safety compliance enforcement, safety participation etc. The prevailing safety culture and safety behaviour at a workplace could determine level of hazards and whether exposure to hazards to could result in harm or not. 


\section{The Present Study}

The present study explored the specific hazards of each of the types of hazards described above that are present in rice farming in Ghana. The prime aim was to identify rice farming hazards and health and safety challenges the farmers encounter in their activities through qualitative approach. There is dearth of research regarding safety hazards and health and safety incidents in production agriculture. Indeed, Bosompem and Mensah (2012) indicated that very little research attention has been given to occupational hazards among cocoa and other farm workers. They noted further that a few studies investigated hazards associated with the use of agrochemicals, but ignored the hazards associated with other farming activities. I have also come to the conclusion from review of the limited literature regarding health and safety in production agriculture that biological, ergonomic and physical hazards have been ignored in research. Again, the few studies that investigated hazards and injuries production agriculture were also in cocoa farming (e.g. Bosompem \& Mensah, 2012; Muilerman, 2013), but little (if any) is known about rice farming health and safety hazards and challenges in Ghana. Given that rice is one of the most consumed cereals in Ghana, it is important to investigate hazards and safety challenges that the rice farmers face.

ILO estimates indicate that about 160 million people suffer from occupational diseases and 2 million people die every year as a result of occupational accidents and work-related diseases and injuries. The agricultural sector constitutes one of the most hazardous workplaces. Studies in the US regarding injuries to farm workers in 1979, 1980, and 1981 which used national statistics (Reesal, Hagel, Pahwa, Domoney, Dosman, \& McDuffie, 1992) indicated that about 300 youth die each year from farm injuries and 23,500 suffer nonfatal injuries. Also, more than $50 \%$ of victims of fatal farm injuries die because of the distance of the farm, nearly $20 \%$ die on their way to a hospital, and only about $10 \%$ survive and get treated.

About 167 agricultural workers suffer a lost-work-time injury, and about 5\% result in irreparable deformity of workers everyday (US Labour Statistics, 2012). Exposure to agrochemicals also poses high risk for farm workers, because they may cause poisoning, work-related health problems or even death (ILO, 2010).

In Ghana, McNeill and O'Neill (1998), in a study with Ghanaian farmers found that $76 \%$ of the respondents suffered musculoskeletal disorders, $77 \%$ suffered lower back pains, and 50\% burns, among others. Bosompem and Mensah (2012) and Muilerman (2013) also found that Ghanaian Cocoa farmers experience various forms of injuries and disabilities from their farming activities. As Ghana seeks to increase rice production and reduce the quantity of rice imported into the country, there is the need to ensure that farmers are healthy and safe.

To achieve success of health and safety management at the work place requires proper appreciation and identification of risk factors, strong management commitment, and collaboration among safety and health professionals, employees and their associations/ organisations, and management. The nature of hazards at any workplace determines what constitutes safe work behaviour and when or what safety measures workers need to put in place (Weinstein, 2000).

\section{Methodological Approach}

The line of inquiry in the study was exploratory (qualitative) research approach. Robson (2002) indicates that an exploratory study investigates or explores what is happening and seeks new insights through asking questions and assessing phenomena in a new light. Creswell (2007) defines qualitative research as " $a$ means for exploring and understanding the meaning individuals and groups ascribe to social or human problems" (p. 5). According to Patton (1990), qualitative research approach enables researchers to get close to the problems throughout the field work and brings their personal understandings and experiences into any recommendations that may emerge from the data collected. The use of qualitative approach made it possible for observations and interviews to be conducted and responses recorded directly without any obstacles from the participants (Hair, Bush, \& Ortinau, 2000).

\subsection{Sample and Sampling Procedure}

The sample for the study consisted of key informants from three conveniently selected rice irrigation schemes. Given that different levels of an organisational hierarchy have different influences on the safety perception and behaviour, the sample for this study included the scheme managers, supervisors (or extension officers) and experienced rice farmers. The theoretical sampling procedure was employed. A perfect representation of the respondents was therefore not sought, and the sample was made purposefully, focusing on key informants who would provide the needed information rather than randomly (Ezzy, 2002). Accordingly, sampling and interview continued until no new data was forthcoming, a point of data redundancy or data saturation (Lincoln \& Guba, 1985). The characteristics of the respondents are presented in the table below. 
Table 1: Characteristics of Interview Respondents

\begin{tabular}{lllll}
\hline Participant (RP) & Gender & Age & Status & Educational level \\
\hline 1 & Male & 62 & Ex-scheme Manager/ Farmer & First degree \\
2 & Male & 61 & Ex scheme Manager/ Farmer & First degree \\
3 & Female & 39 & Extension Officer & First degree \\
4 & Male & 41 & Scheme Manager & First degree \\
5 & Male & 43 & Rice Farmer & Middle School \\
6 & Male & 54 & Rice farmer & Middle School \\
7 & Male & 34 & Rice Farmer & SHS \\
8 & Male & 68 & Chief Farmer & Middle School \\
9 & Male & 65 & Rice Farmer & Middle School \\
10 & Female & N/A & Rice Farmer & Middle School \\
\hline
\end{tabular}

\subsection{Data Collection Instrument}

The aim of the study was to identify specific health and safety hazards that the rice farmers are exposed to in their farming activities. Accordingly, primary data was collected through the use of semi-structured interview guide and observation guide to obtain relevant information regarding rice farm hazards and incidents in rice farming. The interview guide consists of 10 open ended questions that focused on identifying hazards associated with rice farming activities, and follow-up and probing questions were asked where necessary to get further. The interview guide consisted of items that explored hazards at the pre-planting stage (land preparation and nursing), planting stage, crop management stage, harvesting and post-harvesting stages.

\subsection{Data Collection Procedure}

The data were collected through interviews to identify hazards specifically prevalent in Ghanaian rice farming. The interviews were conducted mainly in the English Language and audio recorded since all the respondents obtained at least a basic level of education and could speak the English Language. During the interviews and visits to the farm sites, observations were also made to see how the farmers carried out their farming activities and these were recorded in a field note book. Interaction notes were also taken since recording equipment may not play, as noted by Creswell (2007).

Follow-up questions were used to probe and clarify interviewees' responses as suggested by Warren (2001) and Burnell (2007). Each interview lasted between 35 to 45 minutes. At the end of the entire interview, random portions of the tapes were played back for participants to verify the authenticity and also ensure the validity or trustworthiness of the data. All the participants confirmed what was played was a true reflection of what they intended to say. In a few cases, the respondents added new information they felt were relevant.

\subsection{Data Analysis Procedure}

Given that there were specific research objectives for this study, the theoretical (deductive) thematic analysis (Patton, 1990) was used to analyse the data. Thematic analysis involves analyzing and reporting patterns within data, and minimally organizing and describing the data set in rich detail (Braun \& Clarke, 2008). According to Braun and Clarke, thematic analysis is not linked to any pre-existing theoretical framework and so could be used within different theoretical frameworks.

The audio records of the interviews were transcribed verbatim and Braun and Clarke's (2008) six step thematic analysis was used for the qualitative data. The six steps are briefly described below:

Becoming familiar with the data:

The transcribed data was read and re-read so as to become very conversant with the content. At this stage, notes of initial ideas obtained from the transcripts were written for further consideration.

Generating initial codes:

This stage involved coding the unique features of the data in a systematic fashion across the entire data set and the collation of data relevant to each code. Searching for themes:

At the third stage, the codes generated at the previous stage were collated into potential themes. Boyatzis (as cited in Braun and Clarke, 2008) indicated that themes could be identified at either the theoretical (deductive) or inductive (bottom up) way. The deductive approach was used in this study. Each transcript was thoroughly examined and systematically read and re-read, highlighting important statements and grouping recurrent themes, patterns, and ideas as they emerge from the data.

Reviewing themes:

The themes were checked in relation to the coded extracts (stage one) and the entire data set (stage two), still guided by the research objectives of the study.

Defining and naming themes. 
The themes were refined based on the specifics of each theme and the overall story the analysis tells. The precise definitions and names for each theme were done at this stage (e.g. biological hazards).

Producing the report:

The final stage of the analysis involved the selection of vivid, compelling extracts and examples from the data set for presentation in relation to the research objectives. The analysis was then related to the research question and literature (implication and significance of the themes). The summarized report of the analysis was then presented.

\subsection{Trustworthiness of the Study}

Lincoln and Guba (1985) suggested the criteria of credibility, neutrality or confirmability, consistency or dependability and applicability or transferability for ensuring trustworthiness of a qualitative investigation. These quality criteria have been widely accepted and applied in qualitative research (Koch, 2006) and so were utilized in this study as well.

\section{Results and Discussion of Findings}

The first objective of the present paper was to identify health and safety hazards to which rice farmers in Ghana are exposed. The hazards associated with rice farming activities at various stages of farming operations were explored:

1. Pre-planting: land preparation

2. Planting

3. Crop management

4. Harvesting, and

5. Post-harvesting

The farming activities that are carried out at each stage of the farming process were explored through interviews and observation of anything or actions that were likely to cause harm. The interview therefore focused on the specific activities that are involved at each of the stages afore-mentioned and the tools that are used. Features of the rice fields that were likely to cause harm or health challenges were also observed and noted. The themes and sub-themes that emerged were organised at each stage and presented. Finally, the types of hazards identified have been summarized in a table at the end of the analysis.

\subsection{Pre-planting activities and hazards}

The pre-planting activities involved in rice farming include: clearing of land manually with cutlass, application of weedicides or occasional burning of field to kill the grass to clear the field, watering of the field to soften it for tilling, tilling and crossing, levelling of field and nursing of seedlings.

Clearing of Field

Analysis of the transcripts indicate that when the rice field is bushy, the main mode the farmers use in clearing it is spraying the grass with weedicides to kill the grass before tilling (ploughing). Occasionally, cutlasses are used to clear and burn the grass before the ploughing is done.

A 54 year old male rice farmer said in an interview:

Now that I have harvested over a month ago, if I go back there, it would be bushy. So first of all,

I have to buy chemical to spray and kill all the grass. Then use cutlass to weed all the edges that the chemical couldn't kill to make it clear (Respondent, RP 6).

An Extension Officer also explained the field preparation process in these words:

You start preparing the land by weeding the grass with cutlass, or killing the grass with chemical.

After that you spill water on the field, and then the power tiller comes to till the land for you

(Female, 39 years old, RP 3).

Another male farmer had this to say:

You first buy weedicide and spray to kill the grass. Then you call the "Agriman" (Agric man, ie,

the operator of the power tiller), to come and till the field for you (34 years old, RP 7).

The main modes of field clearing are the use of weedicide and cutlasses. These activities expose the farmers to all forms of hazards: chemical hazards, ergonomic hazards, biological as well as physical hazards. Spraying with the weedicide exposes them to chemical hazards, and this has been one of the greatest hazards that farm workers are exposed to. Also, using the cutlass to clear the bush exposes the farmers to ergonomic hazards (awkward sustained posture) as they bend to weed. There may also be reptiles (e.g. snakes) and other harmful creatures in the bushy rice field. The use of the cutlass itself is a hazardous activity, not forgetting the scorching sun and the grass being cleared which could also cause some health challenges to the farmers. In addition, they occasionally burn the field and are exposed to fumes and other gaseous particles. The hazards at this stage therefore are: agro-chemical, sharp implements, awkward work posture, smoke from burning field, etc

Tilling, Crossing and Levelling

Tilling is the process of ploughing the rice field to make it cultivatable. This is done by a hired operator who uses 
the power tiller machine. Tilling tends to be an activity for special people, because of that the operators were not involved in the study. Thus, the tilling process does not pose any major challenge to the rice farmer; though hazardous to the operator of the machine.

A 68 year old respondent (the Chief Farmer) described the rice production process in these words:

You start by weeding the grasses with cutlass, or killing the grass with chemical. After that you spill water on the field, and then the power tiller comes to till the land for you. After the tilling, if you want to do transplanting (instead of broadcasting or dibbling), they (extension officers) will come and make or help you to make nursery beds for you to nurse the seedlings. After the nursing, in two weeks time the machine will come and do the crossing for you. After crossing, if you want to plant in line, you go in for marker to mark the lines for you before you plant. Then those who don't want to do the planting because of monetary issues, they do broadcasting.

Then broadcast too, you have to do scaring of the birds not to come and eat the seed. Especially, sparrows or doves would eat everything on the field. You have to do away, away (i.e. creaming to scare birds) on it for two weeks (RP 8).

The hazards identified in relation to this activity include: Awkward posture, sun rays, screaming Nursing of Rice Seedlings

Farmers who want to do transplanting may have to nurse their seeds before tilling the field. They would have to make seedling bed and nurse the seeds. This also involves the use of hoe, shovels and other farm implements. The second tilling (crossing) and levelling off the field is done when the seedlings are ready for transplanting. The levelling is sometimes done manually, where a board is dragged over the field by a number of men to make it level. This could also be done by the tiller towing the levelling board over the field.

The most prevalent hazards identified at this stage have to do with exposure to sharp farm implements (e.g. hoe), the sun, and awkward posture. When levelling the field manually, the farmers may also over exert themselves which may cause harm to the people involved. Table 2 presents a summary of the hazards associated with preplanting activities.

Table 2: Summary of Pre-planting Activities and Hazards

\begin{tabular}{|c|c|c|}
\hline Activity & Processes & Hazards \\
\hline Clearing of rice field & $\begin{array}{l}\text { Weedicide spraying, clearing with } \\
\text { cutlass }\end{array}$ & $\begin{array}{l}\text { Agro-chemical, cutlass, awkward sustained } \\
\text { posture, sun rays, insects, reptiles etc }\end{array}$ \\
\hline $\begin{array}{l}\text { Watering of field to } \\
\text { soften for tilling }\end{array}$ & $\begin{array}{l}\text { Cooperative opens water from dam } \\
\text { and farmers direct onto their fields }\end{array}$ & Sun rays, objects in soil, slippery bonds \\
\hline Tilling and crossing & $\begin{array}{l}\text { Tiller machine operator hired to till } \\
\text { and later cross the rice field }\end{array}$ & No major hazards to farmers \\
\hline Levelling & $\begin{array}{l}\text { Use of flat board: manually or tow } \\
\text { by tiller to level the field }\end{array}$ & $\begin{array}{l}\text { Sun rays, awkward posture, lifting, objects in } \\
\text { the soil }\end{array}$ \\
\hline
\end{tabular}

4.2 Planting related hazards and injuries/health challenges

Rice planting is normally done in three ways: broadcasting, dibbling and transplanting. The broadcasting method involves spreading the rice seed over the field with the hand. This is not a preferred planting method as birds may eat all the seeds before they geminate. The second method is dibbling. This involves digging and sowing the seed directly into the soil as is done in growing of maize. This process is also not common among the farmers. The preferred planting method is the transplanting.

Transplanting

When the seedlings are ready for transplanting, they are uprooted from the nursery beds and replanted in the rice fields. The field must be watered before transplanting. The farmers have to bend down and use the hands (fingers) to push the seedling into the soil. At this stage, the major hazards include awkward sustained posture for long hours, walking in the marshy rice field bare-footed, and using the fingers to push the seedling into the soil.

The farmers reported, and I also observed snail shells and other objects in the soil that sometimes cause harm to the feet or their fingers. Some farmers use ordinary socks to hold their pair of trousers in place while walking in the rice field. The socks get wet on their feet, which has the potential of causing foot rot. There is a paddy boot which is appropriate for the rice field and could prevent any harm, but the farmers indicated that it was not available for them to use. The Wellington boot was said to be too heavy for the rice field and may get stacked in the soil if used. A summary of the planting activities related hazards are presented in table 3 . 
Table 3: Summary of Planting related activities and hazards

\begin{tabular}{|c|c|c|}
\hline Activity & Processes & Hazards \\
\hline Nursing of seeds & $\begin{array}{l}\text { Preparation of nursery bed manually with } \\
\text { different implements }\end{array}$ & $\begin{array}{l}\text { Use of implements, awkward } \\
\text { posture, sun rays, objects in soil }\end{array}$ \\
\hline $\begin{array}{ll}\text { Marking } & \text { of } \\
\text { line/Transplanting } & \end{array}$ & $\begin{array}{l}\text { Marking is done for row manual transplanting. } \\
\text { Support is obtained from fellow farmers or } \\
\text { hired transplanters }\end{array}$ & $\begin{array}{l}\text { Awkward posture, sun rays, } \\
\text { objects in soil, long work hours }\end{array}$ \\
\hline Filling in & $\begin{array}{l}\text { Manually filling in spaces where transplanted } \\
\text { seedlings are dead }\end{array}$ & $\begin{array}{l}\text { Sun rays, objects in soil, } \\
\text { implement use }\end{array}$ \\
\hline
\end{tabular}

\subsection{Crop management related hazards and injuries}

There are several activities that are involved at this stage. There is constant monitoring of the water level to enable the rice grow well. Water level management is critical, especially when the rice starts booting until the rice starts hedging.

Agro-Chemical Applications

Two weeks after the transplanting, there is application of selective weedicide (e.g. condax, codbos etc.) to kill any weed among the rice. There is also application of fertilizer (NPK or ammonia, about twice).

A 41 year old Scheme Manager indicated that:

...After that you spray your weeds killer. That is a selective herbicide for control of the weed. After that, you broadcast the fertilizer inside the field. Thereafter, you have to be watching if there are some places that are not filled; you do the filling of any gaps. That is about broadcasting!

But we plant in lines. That one too, after two weeks if you see that the rice is doing well, then you spray the selective herbicide before you apply the fertilizer. After that you open the water onto the field. If you see there is enough water for the rice to grow up, you wait for it to grow up. There is a time that you will realize that the fertilizer is finished in the soil. That is another two or three weeks, then you do the second application.

After that you keep visiting the field and be irrigating. Where there is no water, you let water go there (RP 4).

The application of the fertilizer is done manually with the hand by broadcasting. In response to a question about how the agrochemicals are applied, this was the response from a male respondent:

With the fertilizer, you use your hand. For the chemical, we use the machine. The machine has a handle which we use. But for the application of the fertilizer, you must use your hand to broadcast it. After that you find some soap and wash yourself because there is no machine to broadcast fertilizer. Water lets the fertilizer wet; so when it is wet it causes burns (43 year old Farmer, RP 5).

Thus, the fertilizer application and the spraying of weedicides expose the farmers to various chemical hazards. These are likely to cause respiratory and skin challenges, as well as long term lasting effects on the health of the farmers.

Bird Management (Scaring of Birds)

Bird management was a prominent theme that came out as a critical activity of the rice production process. At the hedging stage (i.e. when the rice starts fruiting), the birds are attracted and they start eating the rice. This means the farmer must be on the farm everyday to scare birds. Bird management is a crucial event in the life of a rice farmer. This is done to prevent the birds from consuming all the rice on the field. This is done continuously for about 30 days when the rice is ready for harvesting and harvesting is done. The man with the catapult in hand watches and drives away any bird found on the rice field with dry clay balls thrown by the catapult.

A respondent had this to say: "... if it is hedging then we have to do scaring (drive away birds)" (Female farmer, RP 10).

A 54 year old male farmer explained what scaring involved in these words:

"... Scaring? Yeah, you sack birds. But now there is a method which we are using. We cover it with a net. We use catapult also; we make balls from clay, dry them and then put into the catapult and throw them to drive away the bird. This is done continuously for thirty days" (RP 6).

Another male farmer said:

After the second application of fertilizer, you will realize that the rice has started booting and the birds are attracted and they start eating it. Scaring starts from that time. ... You make a temporary shed on the field and stay there to monitor the rice. When you see the birds come around, you use the catapult to drive them away, or you shout, hey hey hey, away!!! If you won't do it that way, then you have to get a silver bowl and hit it with stick and scream: away! Away!! Away!!!, to drive them away. If the birds come around then you scream and beat 
the bowl: away! Away!! (65 years old, RP, 9).

In response to a question as to whether they do get sore throat as a result of the screaming to scare birds, a respondent responded this way:

"Ooh! Yes. (He laughed). "The moment you get home, you have to go and get some medicine to

treat it. It is very serious. It's one major problem for us" (43 years old male farmer, RP 5).

Another farmer (a female) asserts:

"Scaring of birds is done through shouting and use of catapult. You keep running on the bonds

from one place to the other. You get here and the birds are at the other side, so you have to run back to chase them" (RP 10).

It was observed that bird management or bird scaring is one major activity in rice production. Several methods are used in scaring the birds in Ghana. These include the use of scarecrows, covering the rice with nets, use of cymbals, catapults, shouting etc. The methods that are most commonly used in the farms used in this study are the use of net, catapults and use of cymbals, accompanied with shouting. These, especially the catapult, have been described by the farmers as very hazardous.

“...The catapult can get torn and hit your chest or any other place. We even get injured sometimes” (RP 10).

Another 34 years old farmer had this to say:

"...Sometimes the catapult gets torn and hits our chest, head, eye etc. Someone even had the eye damaged by the catapult" (RP 7).

Running on the bonds have also been described as hazardous by the farmers. The bonds are narrow and may be slippery at times. A 43 year old male farmer mentioned that: "When running on the bond to scare birds you can slip and fall, or stumble in a hole on the ground and fall. We fall all the time. It's normal" (RP 5).

The scaring of birds continues till the rice is ready for harvesting. The hazardous nature of the catapult, slippery bonds, screaming exposure to the scorching sun and the rice grass were some of the hazards identified. The farmers indicated that they frequently fall into the growing rice while running on the bonds to scare the birds. This causes a lot of discomfort to the skin if one does not wear clothing to cover it.

Table 4: Summary of crop management activities and hazards

\begin{tabular}{lll}
\hline Activity & Processes & Hazards \\
\hline Fertilizer application & Hand broadcasting on the field & $\begin{array}{l}\text { Agro-chemicals, sun rays, objects in } \\
\text { soil }\end{array}$ \\
\hline Weedicide spraying & $\begin{array}{l}\text { Mixing of chemical with water and } \\
\text { spraying with machine }\end{array}$ & $\begin{array}{l}\text { Agro-chemicals, sun rays, objects in } \\
\text { soil, lifting of weight }\end{array}$ \\
\hline Water level monitoring & $\begin{array}{l}\text { Constantly monitoring the water levels and } \\
\text { supplying (if needed) on the field }\end{array}$ & $\begin{array}{l}\text { Sun rays, slippery bonds } \\
\text { Bird management }\end{array}$ \\
$\begin{array}{l}\text { Use of catapult and cymbals, creaming, } \\
\text { netting }\end{array}$ & $\begin{array}{l}\text { Use of catapult, creaming, sun rays, } \\
\text { narrow slippery bonds, rice grass }\end{array}$ \\
\hline
\end{tabular}

\subsection{Harvesting related hazards and injuries}

The harvesting of rice in Ghana is done both manually and with the combined harvester. The manual harvesting is done using cutlass and sickle to cut the rice. They are then gathered at a place for threshing.

A 65 year old male rice Farmer had this to say in response to how the harvesting of the rice is done.

Sometimes, you don't get combined harvester so you use the cutlass or sickle. After harvesting then you pack it and thresh. After threshing you have to bring it to the platform for drying. After drying, winnowing and then weighing (RP 9).

Another respondent from another irrigation scheme said:

We were doing the manual harvesting. It is only this farming season that someone brought the combined harvester. But it does not go to mushy (swampy) areas so we use the cutlass to cut the rice from those areas. ... When you harvest, you thresh, then put them in sacks and bring to the space here for drying. After drying, then you winnow. After winnowing, to the mill, then it is ready for weighing and marketing (Ex-Scheme Manager, RP 2).

Threshing of Rice

Manual threshing involved the use of to stick (bumper) to hit the rice till all the rice fall off from the grass. This requires a lot of physical energy. The rice grass could also cause skin irritation if the farmers are not properly dressed to cover the skin.

Drying of Paddy Rice

The next stage after the threshing is trying. The threshed rice (paddy rice) is carried from the farm to the drying platform either with the help of a tractor trailer of individuals carry them on their heads. The rice is spread on canopies on the platform for weeks or few days, depending on the weather condition. When they are well dried, the rice is then taken to the next stage, which is the winnowing stage. The hazards at the dry stage mainly include 
lifting and carrying of bags of rice to the platform. Another health hazard was that when the unshelled rice touches the skin, it causes skin irritation and itching.

A woman drying rice cautioned my research assistant and I when we wanted to help with the drying. She was not part of the interviewees, but her response provided very valuable information:

"Eeei"!![she exclaimed] You will get skin irritation; your skin will itch badly. You can see we are in long sleeve dresses. If you don't do it that way, by the time you finish, you will have rashes all over your hand.

Meanwhile, it was observed that a few of them were not wearing long sleeve dresses. When I enquired why they were not wearing, they told me they were not comfortable in the long sleeve dresses and that they were not going to let the rice touch their skin: "We will be very careful", they said.

Thus, carrying of the rice, exposure to the paddy rice, and exposure to the direct sunshine were the main health and safety hazards involved in the drying process.

Manual Winnowing

This is done to remove stone and other particles from the rice. The manual operated machine removes other particles (and dust) from the rice by winding a lever. The paddy rice is also raised high and poured down for the wind to blow foreign materials from the rice.

A 54 year old rice farmer ( $R P$ 6) who was using the manual winnowing machine said in response to a question as to whether dust and particles from the rice enter their eyes said:

It's serious! Dust enters our eyes very much. I would very much love to use goggles, but I don't have any. You need to use your own money to buy it. This together with gloves, and long sleeves if I get I would use. You need to use protective clothes and glove, those ones too I don't have. There are some who dress nicely before coming to do this. They wear long sleeves and glove to prevent rashes

He also talked about the itchy nature of the paddy rice: "The rice itches very badly. What I am doing now, by the time I finished, you would see rashes all over my hands."

This farmer was in bathroom slippers, so I asked if he wears wellington boots when going to the farm which he responded in the affirmative. Then I asked why he was not wearing it while doing the mowing.

He responded: "This place is not very hazardous like the farm that is why."

Meanwhile, when further probing questions were asked, the farmer indicated that they do not normally use appropriate protective safety wears.

He said: “...We wear socks. But we don't use it; true... If I tell you the truth, we don't use these things most of the time."

Milling of Rice

This is the final stage of the rice production process before it goes to the market or is ready for consumption. The milling is the "shelling" of the rice to get the "pure rice". This process gets the rice ready for final bagging for sale or consumption. There is a de-stoner in the mill that also removes stones and other particles from the rice. The hazard involved here mainly has to do with the lifting and carrying of the bags of rice to the mill and from the mill. The weight might be too heavy that may cause physical strain.

The milling process ends the production phase of rice. The milling process gives the wholesome rice which is bagged, weighed and sealed for sale. The rice is therefore ready at this stage for consumption and sale.

Table 5: Summary of Harvesting and Post-harvesting Related Activities and Hazards

\begin{tabular}{|c|c|c|}
\hline Activity & Processes & Hazards \\
\hline $\begin{array}{l}\text { Manual } \\
\text { machine }\end{array}$ & $\begin{array}{l}\text { Mostly use of cutlass or sickle to cut the } \\
\text { rice; occasionally use the combined } \\
\text { harvester }\end{array}$ & $\begin{array}{l}\text { Use of sharp implements, awkward posture, sun } \\
\text { rays, rice grass, insects, reptiles, objects in soil, } \\
\text { lifting of weight }\end{array}$ \\
\hline Threshing & $\begin{array}{l}\text { When manual harvesting is done, } \\
\text { threshing is done manually }\end{array}$ & $\begin{array}{l}\text { Repetitive movement, awkward posture, rice } \\
\text { grass and paddy rice, sun rays, lifting of weight }\end{array}$ \\
\hline $\begin{array}{l}\text { Bagging and } \\
\text { conveying }\end{array}$ & $\begin{array}{l}\text { After threshing, the paddy rice is put in } \\
\text { rice bags and conveyed to the drying } \\
\text { platform }\end{array}$ & Paddy rice, lifting of weight, sun rays \\
\hline Drying & $\begin{array}{l}\text { The paddy rice is dried on a platform for } \\
\text { days }\end{array}$ & $\begin{array}{l}\text { Paddy rice, lifting of weight, sun rays, awkward } \\
\text { posture }\end{array}$ \\
\hline Winnowing & $\begin{array}{l}\text { Winnowing is done to remove } \\
\text { unwanted particles }\end{array}$ & $\begin{array}{l}\text { Paddy rice, particles from rice, sun rays, } \\
\text { repetitive hand movement }\end{array}$ \\
\hline Milling & $\begin{array}{l}\text { The dried paddy rice is milled to get the } \\
\text { final consumable wholesome rice. }\end{array}$ & Lifting of weight \\
\hline $\begin{array}{l}\text { Bagging } \\
\text { weighing }\end{array}$ & $\begin{array}{l}\text { The wholesome rice is bagged and } \\
\text { weighed }\end{array}$ & awk \\
\hline
\end{tabular}




\section{Summary of Hazards in the Rice Farm Operations}

As the focus of the study was on the prevailing hazards in rice farming, the various forms of hazards identified at the different stages of rice farming have been summarised and put under the categories of hazards (Kumphon, 2009) in Table 6 below.

Table 6: Summary of Rice Farm Hazards

\section{Chemical Hazards}

Application of agro-chemicals (e.g. fertilizers, pesticides, weedicides)

Exposure to fumes from burning of farm land

\section{Physical/Safety hazards}

Dust or particles from winnowing of rice

Exposure to sun rays

Prolong working hours

Working in marshy rice fields, narrow and slippery bonds

Screaming to scare birds

Presence of snail shells, tree stumps and thorns in the rice field

Lifting of weight (bags of fertilizer, rice etc)

\section{Biological Hazards}

Exposure to animals, insect, snakes etc

Rice grass or paddy rice exposure

\section{Ergonomic Hazards}

Use of catapults to scare birds

Bending or awkward posture at work

Use of sharp farm implements, tools and equipment

Use of farm machines (threshers etc)

\section{Discussion of Findings and Conclusion}

The hazards identified present likelihood of harm or health challenge to the farmers, and most of the hazards cannot be eliminated because they are inherent part of the farming operations. Therefore, appropriate use of PPEs is very necessary to reduce the possibility of harm.

The findings show that rice farmers in Ghana are exposed to various forms of occupational health and safety hazards. The rice farming activities that posed most health and safety challenge to the farmers were the scaring of birds, using the catapult and the manual harvesting and threshing of rice. The use of catapult permanently damaged an eye of a respondent, with others having various forms and degrees of injuries from the use of the catapult.

The findings indicate clearly that farming activities pose a lot of health challenges to farm workers because of the tedious and muscular nature of the work, as observed by Joshi (2002). There are other features or aspects of farming that are inherently hazardous to the health and safety of the farm worker, such as long working hours, weather conditions etc. Joshi indicated that farming has the potential to cause muscular-skeletal disorder, aches, pains etc. As far back as 1989, McNeill and O'Neill investigated the health and safety of farmers engaged in crop production and observed a number of disabilities among the farmers, including lower back pain, chest pain, cutlass injuries etc. Other research conducted in Ghana among Cocoa farmers reported similar safety concerns (Muilerman, 2013; Bosompem \& Mensah, 2012). The Jacklow law firm (2015) also indicated that the common types of farm injuries result from equipment and implement use, pesticides and chemical poisoning, fertilizer burns etc. These were corroborated in the current study with the rice farmers.

Long working hour has been found to be prevalent among the rice farmers in this study. The farmers in the current study indicated that it was not possible to rest during the bird management period (scaring of birds). This is because if one leaves the farm to rest, the birds would consume all the rice. The ILO (2010) observed that long working hours has been one of the main causes of health challenges in farming.

Despite the prevalence of various forms of hazards, it was observed that a great number of the farmers do not wear appropriate PPEs. Consequently, they experience many safety and health challenges. Meanwhile, it seems that the farmers were used to, and had become accustomed to the unsafe ways of working. This observation corroborates Pyykkönen and Aherin's (n.d) observation that risk management principles are not widely used in agriculture. It was observed in the current study that many of the rice farmers acted in an unsafe manner, even though they were aware of the health and safety implications.

The findings among the Ghanaian rice farmers seem to be similar to what pertains in other parts of the world in farm practices. Workplace inspection, accident investigation and social science research in the US indicate that there is a deep-seated culture of unwise risk-taking among farm workers. Farmers also often are resistant to officialdom and perceive safety regulations and procedures as great burden (Pyykkönen \& Aherin, n.d). 


\section{Implications for Policy and Practice}

The findings of the present study emphasize the need for intensive education and awareness creation about the importance of the use of appropriate PPEs since most of the hazards are inherent in the farming processes and cannot be completely eliminated. Suutarinen (2003) indicated that scientific contributions on the application of formal safety management theories or practices in farming are not commonly available. This suggests that more empirical research and attention should be given to the agriculture and the informal sector as Ghana desires to ensure food security and create employment avenues for the youth in the agricultural sector. Literature indicates that occupational health and safety has not been generally regarded as integral issue of good farm safety management yet (HSE, 2007). But the time has come for pragmatic measures to make good farm safety management a major concern, especially in countries such as Ghana, where agriculture is the backbone of the economy.

Further research would be needed to investigate the extent of PPEs usage prevalence of health and safety incidents in rice farming in Ghana. Research of this nature would be invaluable in providing holistic health and safety management of rice farming and production agriculture endeavours.

\section{References}

Asumeng, M., Asamani, L., Afful, J., Agyemang, C. B. (2015). Occupational safety and health issues in Ghana: Strategies for improving employee safety and health at workplace. International Journal of Business and Management Review, 3(9), 60-79.

Attride-Stirling, J. (2001). Thematic networks: An analytic tool for qualitative research. Qualitative research, 1(3), $385-405$

Bosompem, M., \& Mensah, E. (2006). Occupational hazards among Cocoa Farmers in the Birim South District in the Eastern Region of Ghana. ARPN Journal of Agricultural and Biological Science, 7(12).

Boyatzis, R. E. (1998). Transforming qualitative information: Thematic analysis and code development. US: Sage publications Ltd

Braun, V., \& Clarke, V. (2006). Using thematic analysis in psychology. Qualitative Research in Psychology, 3(2), 77-101.

Braun, V., \& Clarke, V. (2008). Successful qualitative research: A practical guide for beginners. US: Sage publications Ltd

Bureau of Labour Statistics. (2012). Workplace injuries and illnesses - 2011. U.S. Department of Labour

Burnell, B. (2003). The "real world" aspirations of work-bound rural students. Journal of Research in Rural Education, 18(2), 104-113.

Concha-Barrientos, M., Nelson, D. I., Driscoll, T., Steenland, N. K., Punnett, L., Fingerhut, M. A., \& Corvalan, C. (2004). Selected occupational risk factors. Comparative quantification of health risks: global and regional burden of disease attributable to selected major risk factors. Geneva: World Health Organization, 1651-1801.

Creswell, J. W. (2002). Educational research: Planning, conducting, and evaluating quantitative (pp. 146-166). Upper Saddle River, NJ: Prentice Hall.

Creswell, J. W. (2007). Qualitative enquiry and research design: Choosing among five approaches. US: Sage publications Ltd.

Creswell, J. W. and Plano Clark, V. L. (2007) Designing and Conducting Mixed Methods Research. Thousand Oaks, California; Sage Publications Ltd.

Ezzy, D. (2002). Qualitative analysis: Practice and innovation. Crows Nest, NSW: Allen \& Unwin

Gillham, B. (2000). The research interview. London: Continuum.

International Labour Office. (2010). Global Employment Trends for Youth. Special issue on the impact of global economic crises on the youth. Geneva: Author

Koch, T. (2006). Establishing rigour in qualitative research: the decision trail. Journal of Advanced Nursing, 53(1), 91-100

Kumphon, P. (2009). Pesticide poisoning 2009. Bureau of Epidemiology, Department of Disease Control, Ministry of Public Health. Weekly Epidemiological Surveillance Report, Thailand, 42(17), 257-259.

Lincoln, Y. S., \& Guba, E. G. (1985). Naturalistic inquiry. Beverly Hills, CA: Sage.

McNeill, M., \& O’Neill, D. (1998, April). Occupational disorders in Ghanaian subsistence farmers. In Proceedings of the annual conference of the Ergonomics Society. Chartered Institute of Ergonomics and Human factors, Loughborough, UK (1-3).

Ministry of Food and Agriculture. (2015). Irrigation scheme in Ghana. Republic of Ghana.Ghana Irrigation Development Authority. Retrieved May 15, 2015 from http://mofa.gov.gh/site/?page_id=2987

Ministry of Health/Ghana Health Service (GHS, 2010). Occupational Health and Safety policy and guidelines for the health sector. Ghana: Ghana Health Service

Morse, J. M., \& Chung, S. E. (2003). Toward holism: The significance of methodological pluralism. International Journal of Qualitative Methods, 2(3), 13-20. 
Muilerman, S. (2013). Occupational safety and health on Ghanaian cocoa farms. Baseline report of sustainable tree crops programme, Accra, Ghana, International Institute of Tropical Agriculture (IITA),

Patton, M. Q. (1990). Qualitative evaluation and research methods. SAGE Publications, Inc.

Patton, M. Q. (2002). Qualitative evaluation and research methods (3rd ed.). Thousand Oaks, CA: Sage Publications, Inc.

Pyykkönen, M. \& Aherin, B. (n. d). Occupational Health and Safety in Agriculture, Helsinki, Finland: Ministry of Social Affairs and Health,

Reesal, M. R., Hagel, L., Pahwa, P., Domoney, D., Dosman, J. A., \& McDuffie H. H. (1992). Hearing Loss in Farmers in Rural Saskatchewan. Abstracts, Third International Symposium: Issues in health, safety and agriculture, Saskatoon, Saskatchewan, May 10-15, 92.

Sharife, K. (2011). Ghana: Over 64\% work in agriculture sector, retrieved on 26 ${ }^{\text {th }}$ May, 2015 fromhttp://www.theafricareport.com/West-Africa/over-64-of-employed-ghananians-work-in-theagricultural-sector.html

Shweder, R. A. (1991). Thinking through cultures: Expeditions in cultural psychology. Harvard University Press.

Sikorska-Simmons, E. (2005). Predictors of organizational commitment among staff in assisted living. The Gerontologist, 45(2), 196-205.

Silva, S., Lima, M. L., \& Baptista, C. (2004). OSCI: An organisational and safety climate inventory. Safety Science, 42, 205-220.

Simon, M. \& Goes (2012). Dissertation and Scholarly Research: Recipes for dissertation. Retrieved August 21, 2016 from $w w w$.dissertationrecipes.com

Warren, N. (2001). Work stress and musculoskeletal disorder etiology: The relative roles of psychosocial and physical risk factors. Work, 17, 221-234.

Weinstein, N. D. (2000). Perceived probability, perceived severity, and health-protective behaviour. Health Psychology, 19, 65-74. doi:10.1037/0278-6133.19.1.65 